\title{
Analysis on the Income Effect of Farmers' Cooperative Management: Based on the Chinese Practice
}

\author{
Wen Hua ${ }^{1}$ \\ 1 School of Economics, Central University of Finance and Economics, Beijing, China \\ Correspondence: Wen Hua, Shahe Higher Education Park, Changping District, China. E-mail: \\ 15248120515@163.com \\ Received: September 7, 2020 \\ Accepted: October 20, 2020 \\ Online Published: November 6, 2020 \\ doi:10.5539/ijbm.v15n12p103 \\ URL: https://doi.org/10.5539/ijbm.v15n12p103
}

\begin{abstract}
This paper makes a theoretical analysis of farmers' income and career choice under the two modes of traditional and cooperative management, demonstrates the "direct effect" and "indirect effect" of cooperative operation on farmers' income, and puts forward three influence mechanisms: (1) cooperative operation improves traditional agricultural operation through institutional advantages, making agricultural economy obtain Pareto improved income by operational efficiency; (2) cooperative operation can adjust the imbalance between supply and demand of skilled labor between agricultural and non-agricultural sectors, which makes agricultural economy obtain Pareto improvement income by optimizing the use of labor elements; (3) cooperative operation reduces the skill leverage of non-agricultural employment of labor force under the traditional agricultural management model by providing more career choices for labor force, and promotes the equal distribution of farmers' income. On this basis, this paper apply the 1995-2018 National Household Survey Data, using the continuous DID model to verify the mechanism of cooperative operation on farmers' income.
\end{abstract}

Keywords: Farmers' cooperative management, improvement of management efficiency, improvement of utilization of labor elements, income structure, income distribution

\section{Introduction}

In the middle and late 1980s, the growth rate of Chinese farmers' income began to slow down, and even stagnated in some years. The increasing income gap between urban and rural areas and the imbalance of factor distribution made the agricultural development be the weakest link in China's overall economic development. Many scholars attribute it to the disappearance of "institutional dividend" and the transfer of "industrial center". If the transfer of "industrial center" is driven by external factors determined by economic system reform, then the "disappearance of institutional dividend" of small-scale peasant operation is the fundamental reason for the lag of agricultural development. Since the early 2000s, the central government attached great importance to the innovation of agricultural operation organization. Document No. 1 of the Central Government (from 2004 onwards) has promulgated a series of supporting policies about the cultivation of new agricultural management entities. According to statistics, by the end of October 2019, there were 2.203 million registered farmers' cooperatives across the country, radiating nearly half of the country's farmers.

Cooperative management has an impact on farmers' income from two path. One is the direct path: the cooperative organization directly affects the farmers' income through its unique functions (such as improving market competitive position, reducing market risk, reducing transaction costs, achieve economics of scale, etc.). The other is indirect path: the cooperative organization indirectly affect farmers' income by influencing the flow of production factors within families, between urban and rural areas and between regions. Judging from experience, under the impact of the above two paths, the impact of cooperative management on farmers' income is not only reflected in the structure of farmers' income, but also reflected in the distribution of farmers' income. The purpose of this paper is to investigate the impact of farmers' cooperative management on farmers' income from the perspective of income structure and income distribution, and to explore the mechanism behind it.

From the research results, there are achievements on the "income increase and poverty reduction" effect of cooperative operation on income (Fischer \& Qaim, 2012; Vandeplas et al, 2013; Verhofstadt \& Meartens, 2015; Wang Xiaoping, 2012; Qi Lin \& Zhu Qing, 2013; Zhang Qingliang, et al., 2017), and generally agree that its effect depends on the realization of the functions of various services provided by cooperative organizations 
(Hellin et al, 2009; Develtere et al, 2008; Valentinov \& Iliopoulos, 2013; Abebaw \& Haile, 2013; Peng Wenhuan \& Huang Zuhui, 2017). However, when considering the heterogeneity of members, scholars have not reached a consensus. For example, many scholars affirmed the positive externalities of cooperative operation on poverty (Wen Xue et al., 2019; Liu Yuxin, 2017; Sun Yafan, 2003; Zhang Minsheng, 2009; Yu Liyan et al., 2010; Sun Yanhua et al., 2007). However, from the perspective of resource endowment differences, some scholars pointed out that poor farmers do not have absolute advantages in cooperative organizations compared with rich farmers. Such as,the poor are even more difficult to obtain access qualifications, even if they have access qualifications, they still encounter unequal treatment in business, which limits the "income increase and poverty reduction" effect (shylendre, 2013). Besides, some scholars have pointed out that the proportion of extremely poor or rich farmers in cooperative organizations is relatively small, and that cooperative operation presents more "income increasing" effect on medium-sized farmers (Mercer, 2002).

The above research has a certain reference value for understanding the relationship between cooperative management and farmers' income, but it lacks the investigation of its realization path. Therefore, the contribution of this paper is to make up for the defects of the existing research from the path of the impact of cooperative management on farmers' income. The chapters of this paper are arranged as follows: The second part carries out theoretical analysis and puts forward research hypotheses; The third part introduces data and methods; The fourth part tests hypotheses; The fifth part further analyzes the influence mechanism; The sixth part gives conclusions and policy suggestions.

\section{Theoretical Analysis and Hypothesis}

China's agriculture is characterized by small per capita cultivated land area, scattered land distribution and extensive concentration of labour, which makes the traditional agriculture face the problem of low income of farmers. In view of this problem, it is a considerable choice for the current agricultural economy to improve the efficiency of traditional agriculture and the deficiency of factors utilization through cooperative management of farmers. Next, we use a simple analysis framework to make a comparative analysis of the farmers' income under the traditional small-scale agricultural management and cooperative management mode.

\subsection{Farmers' income under the Traditional Small-scale Agricultural Management}

Consider a two sector (agricultural and non-agricultural) economy composed of labor and land elements, in which labor is a flowable factor, and each unit of labor force can only choose one of the sectors to invest; land is a unflowable factor, which is fixed for a long time; labor has heterogeneous skills $h$, and is continuously distributed in the range of $H=\left[h_{L}, \mathrm{~h}_{H}\right]$ values. $L_{\mathrm{h}}$ represents the labor supply of each skill level, and its sum constitutes the total labor force of agricultural economy. Based on the above assumptions, this paper defines the farmers' income equation under the traditional agricultural management mode as follows:

$$
I_{a g}=P^{*} Q-C_{a g}=P^{*} \bar{R}^{*} \operatorname{Ln}(h+1)-C_{a g}
$$

Where $Q$ is the output of the agricultural sector, $P$ and $C_{\mathrm{ag}}$ is the price of agricultural products and agricultural production expenditure respectively, $\bar{R}$ is the area of cultivated land. At the same time, because the labor force is assumed to be a flowable factor, the non-agricultural income of farmers with the same skill level can be defined as:

$$
I_{n a}=W-C_{n a}=\bar{W}_{n a}+r_{n a} h+\bar{R}-C_{n a}
$$

Where $\bar{W}_{n a}$ is the minimum wage level of the non-agricultural sector, $r_{n a}$ is the marginal reward per unit skill level, $C_{n a}$ is the total cost of non farm transfer, $\bar{R}$ is the land rent. As shown in Figure 1, when the difference between the above two formulas satisfy the conditions $I_{\text {ag }}\left(h_{L}\right)>I_{n a}\left(h_{L}\right)$, it can always be found $\tilde{h}$ that the skilled labor force $h_{L} \leq h<\tilde{h}$ is more inclined to choose traditional agricultural management, and the skilled labor force $\tilde{h}<h \leq h_{H}$ is more inclined to choose non-agricultural sector. Based on this, it can be found that compared with the traditional agricultural management, the employment opportunities in the non-agricultural sector have brought certain Pareto improvement benefits for the agricultural economy. When the labor force with skill level $\tilde{h}<h \leq h_{H}$ all choose non farm working, the Pareto improvement benefit is as follows:

$$
I_{w e l}=\sum_{\tilde{h}}^{h_{H}} L_{h} *\left(\bar{W}_{n a} * r_{n a} h+\bar{R}-C_{n a}\right)-\sum_{\tilde{\mathrm{h}}}^{h_{H}} L_{h} *\left\{P^{*} \bar{R}^{*} \operatorname{Ln}(h+1)-C_{a g}\right\}
$$




\subsection{Farmers' Income under Cooperative Management Mode}

In this paper, we will take the scale economic benefits and the improvement of production efficiency as the "direct effect" of cooperative operation, and the labor distribution efficiency brought by the improvement of career choice as the "indirect effect" of cooperative operation, and more specifically analyze the mechanism of cooperative operation on farmers' income. In the traditional agricultural management mode, farmers make rational decisions between agricultural production and non-agricultural sector according to their skills, while in the cooperative operation mode, farmers need to make rational choices between traditional agricultural management mode, cooperative operation, internal or external employment in agriculture according to their skills. Here, we define the cooperative operation income equation as follows:

$$
I_{c o}=(1+\alpha) * P^{*} \bar{R}^{*} \operatorname{Ln}(h+1)-\mu C_{a g}-C_{\text {co }}
$$

In the formula, $\alpha$ means productivity increase brought by cooperative operation, $\mu$ means cost depreciation brought by cooperative operation, and $C_{\mathrm{co}}$ means organization cost paid by farmers participating in cooperatives. As shown in Figure 2, if the difference between the equation (4) and (1) satisfies the conditions $(1-\mu) * C_{\mathrm{ag}}<C_{c o}$ (the transaction cost reduction benefit of cooperative operation is lower than the organization cost payment), it can always be found $\tilde{h}$ that the skilled labor force $h_{L} \leq h<\bar{h}$ is more inclined to choose traditional agricultural operation because the organizational cost payment is higher than the relative income of cooperative operation.

In addition, when considering the choice of non-agricultural employment, farmers are faced with two kinds of choices, namely, rural internal workers and external workers. Among them, the internal employment income equation is defined as:

$$
I_{a n}=\bar{W}_{a n}+\gamma_{a n} \mathrm{~h}+(1+\tau) * \overline{\mathrm{R}}-C_{c o}
$$

Where, $\tau * \bar{R}$ represents the land dividend reward. In general, the choice of rural internal workers is brought by the new occupation creation of the cooperative management mode. At this time, farmers entrust the right of farmland management to cooperatives, and then engage in the new occupation created by the cooperatives, so as to obtain wage income $\bar{W}_{a n}+\gamma_{a n} h$ and property income $(1+\tau)^{*} \bar{R}$. As shown in Figure 2, assuming that the initial skill level $h_{L}$ satisfy the relationship $I_{n a}\left(h_{L}\right)<I_{\text {an }}\left(h_{L}\right)<I_{n a}\left(h_{L}\right)$ and The marginal reward of unit skill of rural internal workers is lower than that of external workers $\left(\gamma_{\mathrm{an}}<\gamma_{n a}\right)$, the income equation line of farmers' cooperative operation first meet with the income equation line of internal transfer of farmers, and then intersects with the equation of external transfer. At this time, the labor with skill level $\bar{h}<h<\hat{h}$ is more likely to engage in cooperative agricultural production, the labor with the skill level $\hat{h}<h<\dot{h}$ is more inclined to transfer within the agriculture, and the labor with the skill level $\dot{h}<h \leq h_{H}$ is more inclined to transfer outside the agriculture. Thus the Pareto improvement benefits are as follows: 


$$
\begin{aligned}
& \sum_{\bar{h}}^{\hat{h}} L_{h} *\left\{(1+\alpha) * P * \bar{R} * \operatorname{Ln}(h+1)-\mu C_{\mathrm{ag}}-C_{\mathrm{co}}\right\}-\sum_{\bar{h}}^{\hat{h}} L_{h} *\left\{P^{*} \bar{R} * \operatorname{Ln}(h+1)-C_{a g}\right\}+ \\
& \sum_{\hat{h}}^{h_{h}} L_{h} *\left\{\bar{W}_{a n}+\gamma_{a n} h+(1+\tau) \bar{R}-C_{c o}\right\}-\sum_{\hat{h}} L_{h} *\left\{P^{*} \bar{R} * \operatorname{Ln}(h+1)-C_{a g}\right\}+ \\
& \sum_{h}^{h_{H}} L_{h} *\left\{\bar{W}_{n a}+\gamma_{2} h+\bar{R}-C_{n a}\right\}-\sum_{h}^{h_{H}} L_{h} *\left\{P^{*} \bar{R} * \operatorname{Ln}(h+1)-C_{a g}\right\}+
\end{aligned}
$$

\subsection{The Impact of the Transformation from Traditional Operation Model to Cooperative Operation Model}

Compared with the traditional agricultural management mode, the cooperative operation mode has certain institutional advantages, and this potential income makes farmers have cooperative operation motivation. However, due to the existence of organizational costs, not all traditional agricultural operators can benefit from it. In the production function with labor skill as the only endogenous variable, as shown in figure 2, the workers with lower skill level still prefer to adopt traditional agricultural management, while those with skill level $\bar{h}<h<\hat{h}$ tend to adopt cooperative management. As the above Pareto improvement benefits are brought by the institutional advantages of cooperative operation, rather than through the optimal utilization of labor elements, it can be regarded as a "direct effect".

Hypothesis 1: Cooperative operation improves traditional agricultural management through institutional advantages, which makes agricultural economy obtain Pareto improvement benefits brought by institutional advantages.

As mentioned above, in the traditional agricultural operation mode, the Pareto improvement benefits of agricultural economy mainly come from the higher wages paid by the non-agricultural sector for the potential skills of highly skilled workers. However, Guo Jianxiong and Li Zhijun (2009) pointed out that this form of benefits will make the agricultural economy suffer from the "loss" of high-quality labor force and can not achieve long-term development. Moreover, when the skill of the labor force is generally distributed in the middle and low level, or the non-agricultural sector provides less employment opportunities, the Pareto improvement benefits will be reduced or become less obvious. In the cooperative operation mode, the agricultural economy also achieves Pareto improvement due to the optimal utilization of labor elements. As shown in Figure 2, rural labor not only has the opportunity to work outside of agriculture, but also has the opportunity to work in rural areas due to the occupation creation of cooperative operation. It regulates the imbalance between the supply and demand of skilled labor between agricultural and non-agricultural sectors to a certain extent. As the Pareto improvement is realized by the optimized utilization of labor elements in cooperative operation, it can be regarded as "indirect effect".

Hypothesis 2: Cooperative operation can adjust the imbalance between supply and demand of skilled labor between agricultural and non-agricultural sectors, which makes agricultural economy obtain Pareto improvement benefits from the optimal utilization of labor elements.

When the labor force of agricultural sector is only engaged in traditional agriculture, as shown in Figure 1, its income curve is $\mathrm{ABC}$, while when non-agricultural working are allowed, its income curve changes to $\mathrm{ABD}$, a big turning point appears at point $\mathrm{B}$. The reason for this phenomenon is that, compared with the diminishing marginal return of traditional agricultural production, the non-agricultural sector pays higher marginal reward to the potential skills of workers, that is to say, with the improvement of labor skills, the non-agricultural workers' remuneration is also higher. It can be concluded that in the economies that allow the flow of labor elements, the income gap in the agricultural sector becomes larger due to non-agricultural employment opportunities. Under the cooperative operation mode, the farmer's income curve is ABEFG. At this time, due to the cooperative operation, the income curve is more gentle compared with the traditional agricultural economy.

Hypothesis 3: Cooperative operation promotes the equal distribution of farmers' income by providing labor with more career choices. 


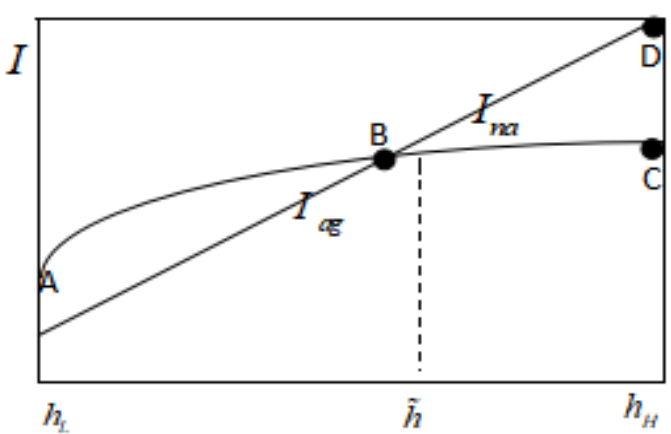

Figure1.Farmers' income of traditional agricultural

Management mode

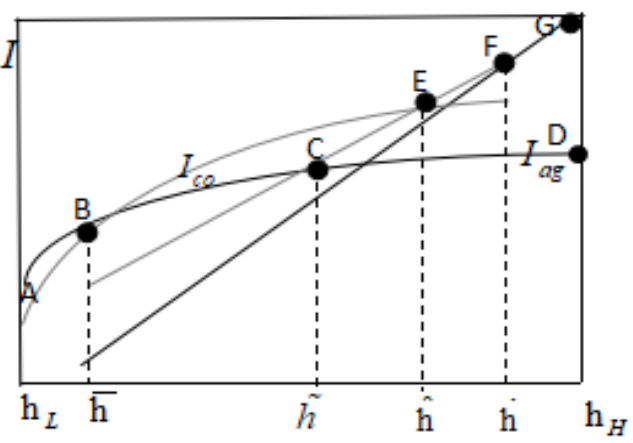

Figure2.Farmers' income of cooperative

Management mode

\section{Data and Methods}

\subsection{Identification Strategy and Model Setting}

In this paper, we use continuous DID model to improve the fixed effect model. The application of continuous DID method needs to satisfy the following two special conditions: (1) the time of policy implementation. In this paper, the support policy of the Central Document No.1 on cooperative management of farmers is used as the time for policy implementation. Without exception, Central Document No. 1 is a guiding principle for China's agricultural economic development strategy. It plays a decisive role in the direction and path selection of China's agricultural economy. China's policy on supporting the cooperative operation of farmers has been mentioned in the Central Document No. 1 of 2004. However, the promulgation of the Law of the People's Republic of China on Farmer Professional Cooperatives on July 1, 2007, so this paper mainly takes 2007 as the time of policy implementation. (2) Appropriate selection of continuous variables. Different from the classical difference in difference (DID) analysis, continuous DID model mainly aims at "one size fits all" policy evaluation. Its core idea is to find an appropriate continuous variable and multiply it with the time dummy variable, so as to identify the impact of the policy. This paper selects the regional agricultural production concentration ratio as the core continuous variable. The reason is that the research shows that the demand of farmers' cooperation is stronger in the areas with high agricultural production concentration. It can be inferred that if the cooperative operation has an impact on farmers' income, the change of farmers' income in areas with high agricultural concentration should also be more significant.

Based on the above analysis, the identification equation is as follows:

$$
I_{j t}=\beta_{0}+\beta_{1} \text { Agri_Pro_Con }{ }_{j t} \times \text { Post }_{t}+\beta_{2} \text { Agri_Pro_Con }{ }_{j t}+\alpha \text { Control }_{j t}+d_{t}+r_{j}+\xi_{j t}
$$

Among them, $j$ represents the region, $t$ represents the time, $I$ represents the proxy variable of farmers' income, Agri_Pro_Con represents the regional agricultural production concentration, and Post represents the dummy variable of policy implementation. Considering the possible time trend and regional characteristics, we also control the time regional fixed effect, $\xi_{j t}$ is random error terms.

\subsection{Data Source and Variable Description}

This paper selects 28 provinces from 1995 to 2018 as samples. The macro data are from China Statistical Yearbook, China Rural Statistical Yearbook, Compilation of the 50 Years since the Founding of New China, China Labor Statistical Yearbook and China Education Statistical Yearbook. The missing data are supplemented by relevant academic papers.

In this paper, farmers' income is taken as an alternative variable to explained variable. From the perspective of income structure, household income is divided into operation income, labor remuneration income, property income and transfer income. Based on the theoretical analysis of the second part, this paper uses operation income to reflect the "direct effect" brought by cooperative operation, and uses labor remuneration income and transfer income to reflect the "indirect effect" brought by cooperative operation. In addition, from the perspective of income distribution, this paper takes the Gini coefficient of farmers' income as its substitute variable. Table 1 reports the definition and descriptive statistics of the main variables, of which panel $\mathrm{A}$ is the descriptive statistics of the explained variables. Panel B is the descriptive statistics of social and economic variables, in which there is 
a large regional difference in agricultural production concentration (the smallest province accounts for $1.5 \%$, the largest province accounts for 10\%), which further explains the rationality of using agricultural production concentration to investigate the impact of cooperative management on farmers' income.

Table 1. Definition and descriptive statistics of main variables

\begin{tabular}{|c|c|c|c|c|}
\hline Variable & Definition & Sample Size & Mean & S.D \\
\hline \multicolumn{5}{|l|}{ Panel A:Explained variables } \\
\hline Operation income & Operation income(Yuan) & 697 & 2568.01 & 1556.30 \\
\hline \multirow{2}{*}{ Labor remuneration income } & Labor remuneration income(Yuan) & 697 & 1929.51 & 2116.31 \\
\hline & Property income(YUAN) & 697 & 132.12 & 138.57 \\
\hline Gini coefficient & $\begin{array}{l}\text { Calculated according to the 5-point method of } 5 \\
\text { income level }\end{array}$ & 533 & 0.30 & 0.05 \\
\hline Internal employment in agriculture & 1-Rural employment / Total employment & 700 & 0.35 & 0.12 \\
\hline External employment in agriculture & $\begin{array}{l}\text { 1-Primary industry employment / Rural } \\
\text { employment }\end{array}$ & 700 & 0.27 & 0.17 \\
\hline \multicolumn{5}{|l|}{ Panel B:Explanatory variables } \\
\hline $\begin{array}{l}\text { Agricultural } \\
\text { concentration }\end{array}$ & $\begin{array}{l}\text { Regional agricultural production value / National } \\
\text { agricultural production value }\end{array}$ & 697 & 3.52 & 2.30 \\
\hline Urbanization rate & Urban population / total population & 700 & 41.36 & 14.07 \\
\hline Average education level & $\begin{array}{l}\text { Proportion of primary school and below } \\
* 6+\text { Proportion of junior high } \\
* 9+\text { sroportion of senior high } \\
* 12+\text { Proportion } \\
\text { above*16(year) }\end{array}$ & 670 & 7.69 & 0.53 \\
\hline Industrial structure & Proportion of primary industry & 697 & 15.94 & 7.59 \\
\hline Labor alternative technology & $\begin{array}{l}\text { Total power of agricultural machinery }(10 \mathrm{KW}) / \\
\text { Cultivated land area }(\mathrm{Ha})\end{array}$ & 697 & 0.47 & 0.30 \\
\hline Non labor alternative technology & $\begin{array}{l}\text { Fertilizer consumption (thousand tons) } \\
\text { Cultivated land area }(\mathrm{Ha})\end{array}$ & 697 & 3.02 & 1.16 \\
\hline Financial support & $\begin{array}{l}\text { Proportion of agricultural support funds in fiscal } \\
\text { expenditure }\end{array}$ & 700 & 9.24 & 3.57 \\
\hline Market openness & Proportion of FDI in GDP & 697 & 7.53 & 0.87 \\
\hline
\end{tabular}

It is worth noting that the premise of selecting agricultural production concentration as a continuous variable to distinguish the control group and the treatment group is that the demand of farmers' cooperative operation is related to the agricultural production concentration degree, That is to say, compared with the areas with low agricultural concentration, the areas with high agricultural concentration have a stronger demand for cooperative management. Figure 1 is a scatter chart drawn according to the proportion of cooperative operation organizations and the proportion of agricultural output value of each province from 2008 to 2018. From the figure, we can see that the proportion of cooperative operation organization in each province has a relatively positive relationship with the proportion of agricultural production output value of each province.

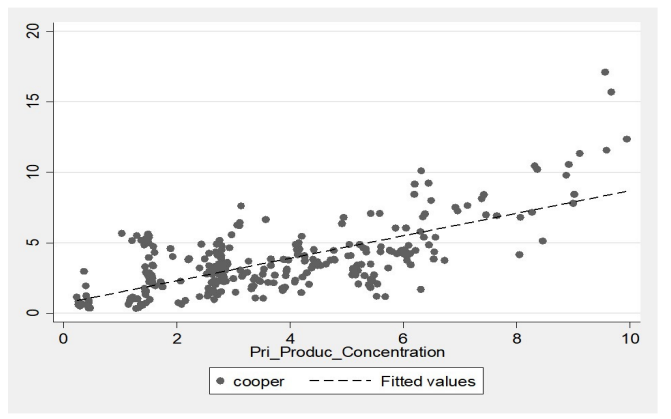

Figure 3. Proportion of cooperative organizations and agricultural output value in each province Data sources: Annual Report of China’s Rural Economic Management, China Rural Statistical Yearbook. 


\section{Hypothesis Test and Result Analysis}

\subsection{Baseline Regression Results}

We use function (8) to test the impact of farmers' cooperative management on farmers' income. The first, second and third columns of panel A are the simple regression results which only control the time and regional characteristics, and the explanatory variables are operation income, labor remuneration income and property income. The results show that the coefficient of the core variable is significantly positive at the $1 \%$ statistical level, indicating that after the promulgation of the "Farmers' Professional Cooperatives Law", the operation income, labor remuneration income and property income of farmers in the areas with high agricultural production concentration are significantly higher than those in areas with low concentration of agricultural production. However, in addition to time and regional characteristics, farmers' income is also affected by social or economic variables. Therefore, the important variables mentioned in the existing literature are controlled in the panel B. Compared with panel A and B, we find that although the estimated coefficient has changed, the significant influence relationship of the two have not changed. The reason is the same as the theory in the previous section. Cooperative operation improves the operation income of traditional agriculture through "direct effect", which makes farmers obtain the potential benefits from the scale expansion, production efficiency improvement and transaction cost reduction brought by cooperative operation. From the regression results of panel B, the agricultural production concentration coefficient (115) means that every $1 \%$ higher agricultural production concentration, farmers' operation income will more about 115 yuan. The coefficient of core variable (87) indicates that after the promulgation of the "law of Farmers' Professional Cooperatives", the income of farmers' operation more by 87 yuan from the original 115 yuan for every $1 \%$ increase of agricultural production concentration, which confirms the research hypothesis that cooperative management can promote farmers' operation income.

In addition, cooperative operation also optimizes the utilization of labor elements in traditional agricultural production through "indirect effect". In the traditional small-scale agricultural management mode, the non-agricultural employment of agricultural sector labor force has the characteristics of "rational select", which makes the agricultural economy fall into the development dilemma caused by the non-agricultural employment of high-quality human capital. The cooperative operation can create new jobs for farmers, and then optimize the utilization of labor elements in agricultural and non-agricultural sectors. The Pareto improvement brought about by the optimization of labor element mainly reflects from the following two aspects: firstly, the increase of labor employment opportunities of internal and external of agriculture, so that the labor remuneration income of farmers has been improved; Secondly, since the labor force liberated from traditional agriculture, farmer has transferred their land management rights to cooperative management organizations, then they also got property income from entrusted management. According to the regression results in the second column of panel $\mathrm{B}$, the agricultural production concentration coefficient (-340) indicates that every $1 \%$ higher agricultural production concentration, farmers' labor remuneration income will be lower about 340 yuan. The coefficient of core variable (217) indicates that after the promulgation of the "Law of Farmers' Professional Cooperatives", the income of farmers' labor remuneration will more by 217 yuan from the original negative 340 yuan for every $1 \%$ increase of agricultural production concentration. At the same time, from the result of column 3, the coefficient (-39) shows that every $1 \%$ higher of agricultural production concentration, the property income of farmers is lower about 39 yuan. The coefficient of core variable (6.4) shows that after the promulgation of the "Law of Farmers' Professional Cooperatives", every $1 \%$ higher agricultural production concentration, farmers' property income is about 6.4 yuan more than the original negative 39 yuan. From the above regression results of labor remuneration and property income, it can be seen that farmers' organizational management has a certain positive effect on farmers' income, which also confirms the research hypothesis that cooperative management has an optimization effect on labor elements.

The fourth column of panel A and B is the regression result with the Gini coefficient of farmers' income as the explanatory variable. Among them, the coefficient of agricultural production concentration is significantly negative at the statistical level of $1 \%$, which indicates that the Gini coefficient in areas with high agricultural production concentration is lower. The underlying reason is as stated in the theoretical part,in the cooperative operation mode, because farmers make the rational career choice in traditional agricultural management, cooperative operation, internal or external employment in agriculture, the space for labor force with various skill levels to obtain the optimum occupation is increased, and then the high-tech leverage of occupation selection in traditional agricultural mode is reduced. 
Table 2. Effect of farmers' cooperative management on farmers' income

\begin{tabular}{|c|c|c|c|c|}
\hline \multicolumn{5}{|l|}{ Panel A:No control variables } \\
\hline & Operation income & Remuneration income & Property income & Gini coefficient \\
\hline \multirow{2}{*}{$\begin{array}{l}\text { Period*Agricultural } \\
\text { concentration }\end{array}$} & $57.195 * * *$ & $217.661 * * *$ & $9.824 * * *$ & $-0.004 * * *$ \\
\hline & $(15.191)$ & $(28.341)$ & $(1.876)$ & $(0.001)$ \\
\hline \multirow{2}{*}{$\begin{array}{l}\text { Agricultural } \\
\text { concentration }\end{array}$} & $190.258 * * *$ & $-340.086^{* * *}$ & $-36.164 * * *$ & -0.004 \\
\hline & $(42.396)$ & $(50.297)$ & $(6.694)$ & $(0.004)$ \\
\hline Regional characteristics & control & control & control & control \\
\hline Time characteristics & control & control & control & control \\
\hline $\mathrm{N}$ & 670 & 670 & 670 & 533 \\
\hline $\mathrm{R}^{\wedge} 2$ & 0.92 & 0.72 & 0.65 & 0.03 \\
\hline \multicolumn{5}{|l|}{ Panel B:Adding control variables } \\
\hline \multirow{2}{*}{$\begin{array}{l}\text { Period*Agricultural } \\
\text { concentration }\end{array}$} & $86.667 * * *$ & $125.419 * * *$ & $6.412 * * *$ & $-0.004 * *$ \\
\hline & $(15.485)$ & $(27.561)$ & $(1.848)$ & $(0.001)$ \\
\hline \multirow{2}{*}{$\begin{array}{l}\text { Agricultural } \\
\text { concentration }\end{array}$} & $114.984 *$ & $-213.674 * * *$ & $-38.791 * * *$ & -0.003 \\
\hline & $(46.178)$ & $(55.728)$ & $(7.103)$ & $(0.004)$ \\
\hline \multirow{2}{*}{ Urbanization } & $-23.357 * * *$ & $86.323 * * *$ & 0.723 & 0.000 \\
\hline & $(4.533)$ & $(8.057)$ & $(0.668)$ & $(0.000)$ \\
\hline \multirow{2}{*}{ Average educational level } & $-501.194 * * *$ & $1357.236^{* * *}$ & 11.432 & 0.018 \\
\hline & $(123.992)$ & $(225.296)$ & $(18.479)$ & $(0.011)$ \\
\hline \multirow{2}{*}{ Industrial structure } & -2.847 & $65.524 * * *$ & $8.932 * * *$ & $-0.003 * * *$ \\
\hline & (7.177) & $(13.344)$ & $(1.025)$ & $(0.001)$ \\
\hline \multirow{2}{*}{ Labor alternative technology } & $546.924 * * *$ & $900.407^{* *}$ & 8.833 & 0.009 \\
\hline & $(136.443)$ & $(276.594)$ & (20.609) & $(0.022)$ \\
\hline \multirow{2}{*}{ Non labor alternative technology } & $114.897^{*}$ & 72.259 & $-19.547 * *$ & 0.001 \\
\hline & $(49.117)$ & $(90.854)$ & $(7.236)$ & $(0.005)$ \\
\hline \multirow{2}{*}{ Financial support } & 2.317 & 16.894 & 1.650 & 0.001 \\
\hline & $(9.730)$ & $(17.341)$ & $(1.272)$ & $(0.001)$ \\
\hline \multirow{2}{*}{ Market openness } & -0.082 & -0.747 & -0.019 & 0.000 \\
\hline & $(0.500)$ & $(1.014)$ & $(0.075)$ & $(0.000)$ \\
\hline Regional characteristics & control & control & control & control \\
\hline Time characteristics & control & control & control & control \\
\hline $\mathrm{N}$ & 670 & 670 & 670 & 533 \\
\hline $\mathrm{R}^{\wedge} 2$ & 0.92 & 0.74 & 0.70 & 0.09 \\
\hline
\end{tabular}

\subsection{Robustness Test}

We will test the robustness from the following aspects: first, change the construction method of the treatment group and the control group; Second, change the selection range of variables; Third, change the selection of continuous variables.

\subsubsection{Change the Construction Method of the Treatment Group and the Control Group}

In the baseline regression, agricultural production concentration is used as a continuous variable to estimate the model. However, the typical DID method needs to have a clear distinction between the treatment group and the control group. In this paper. The former 14 provinces of proportion of cooperative organizations by 2018 were set as treatment group, and the latter 14 provinces were set as the control group, then the typical DID method is used. The reason why this method has a certain value is that if the cooperative operation has an impact on the farmers' income, the provinces with more cooperative organizations have more significant changes in the 
farmers' income structure and income distribution than those with less cooperative organizations. Therefore, if the difference between the two groups of samples passes the significance hypothesis, it can confirm the effect of cooperative management on farmers' income. Table 3 shows the empirical results. From the conclusion, the hypothesis obtained in the theoretical part is still valid.

Table 3. DID estimation by artificial construction

\begin{tabular}{llllllllll}
\hline & $\mathrm{C}$ & $\mathrm{T}$ & $\mathrm{D}(\mathrm{TC})$ & $\mathrm{C}$ & $\mathrm{T}$ & $\mathrm{D}(\mathrm{TC})$ & $\mathrm{DID}$ & $\mathrm{T}$-value & Total \\
\hline \multirow{2}{*}{ Operation income } & 232.128 & 282.642 & 53.514 & 1194.118 & 1890.868 & 696.751 & 643.237 & $4.36^{* * *}$ & \\
& 166 & 168 & & 168 & 168 & & & & 670 \\
Remuneration & 1182.003 & 961.459 & 220.544 & 2084.645 & 3057.145 & 972.500 & 1193.044 & $5.63^{* * *}$ & \\
income & 166 & 168 & & 168 & 168 & & & & 670 \\
& 95.352 & 91.286 & -4.067 & 160.374 & 217.480 & 57.106 & 61.172 & $3.97^{* * *}$ & \\
Property income & 166 & 168 & & 168 & 168 & & & & 670 \\
& 0.333 & 0.328 & -0.004 & 0.302 & 0.261 & -0.041 & -0.036 & $4.971^{* * *}$ & \\
Gini coefficient & 142 & 143 & & 138 & 110 & & & & 533 \\
\hline
\end{tabular}

\subsection{Change the Selection Range of Variables}

In the baseline regression, this paper mainly uses the proportion of agricultural output value of each province as the proxy variable of agricultural production concentration degree. However, one possible worry is that the proportion of agricultural output may produce further aggregation due to the promulgation of the "Farmers' Professional Cooperatives Law". In order to avoid this interference, this paper selects the average value of the proportion of agricultural output value of each province before the promulgation of the law to replace the original indicators of the proportion of agricultural output value of different provinces in different years, and then re-estimate the model. Table 4 panel $\mathrm{A}$ is the estimation result, which shows that the conclusion obtained in the baseline regression is still valid.

In addition, after 2012, the caliber of China's Household Survey Data changed from the statistical net income to per capita disposable income. There are mainly two solutions to the problem of caliber inconsistency: one is to directly eliminate the samples before or after the year of caliber inconsistency; the other is to estimate by piecewise function. In this paper, the first method is used to re-eliminate the model. From the conclusion of panel B in Table 4, the results are consistent with the estimation of the basic model.

Table 4. Change the selection range of variables

\begin{tabular}{|c|c|c|c|c|}
\hline \multicolumn{5}{|l|}{$\overline{\text { Panel A }}$} \\
\hline & $\begin{array}{l}\text { Operation } \\
\text { income }\end{array}$ & Remuneration income & $\begin{array}{l}\text { Property } \\
\text { income }\end{array}$ & Gini coefficient \\
\hline Period*Agricultural & production $69.939 * * *$ & $184.632 * * *$ & $8.373 * * *$ & $-0.004 * *$ \\
\hline concentration & 15.074 & 26.166 & 1.82 & 0.001 \\
\hline Macro control variables & control & control & control & control \\
\hline Regional characteristics & control & control & control & control \\
\hline Time characteristics & control & control & control & control \\
\hline $\mathrm{N}$ & 670 & 670 & 670 & 533 \\
\hline $\mathrm{R}^{\wedge} 2$ & 0.91 & 0.84 & 0.70 & 0.09 \\
\hline \multicolumn{5}{|l|}{ Panel B } \\
\hline Period*Agricultural & production $62.921 * * *$ & $123.649^{* * *}$ & $9.101 * * *$ & $-0.004 * * *$ \\
\hline concentration & 11.571 & 14.272 & 1.704 & 0.001 \\
\hline Macro control variables & control & control & control & control \\
\hline Regional characteristics & control & control & control & control \\
\hline Time characteristics & control & control & control & control \\
\hline $\mathrm{N}$ & 670 & 670 & 670 & 533 \\
\hline$\underline{\mathrm{R}^{\wedge} 2}$ & 0.89 & 0.80 & 0.82 & 0.13 \\
\hline
\end{tabular}




\subsection{Change the Selection of Continuous Variables}

Comparatively speaking, the promulgation of the law belongs to exogenous policy, that is to say, the introduction of this law is less affected by social and economic indicators, and basically satisfy the assumption of randomness. However, it is worth noting that although farmers' income in areas with high agricultural concentration is more likely to be affected by cooperative operation, the potential income of cooperative operation may further affect agricultural production concentration. Therefore, there may be endogenous problems between agricultural production concentration and farmers' cooperative management. Therefore, the paper uses the proportion of agricultural cultivated land as the proxy variable of agricultural production concentration. This index is more exogenous than the proportion of agricultural output value of the baseline regression. Table 5 shows the regression results after using cultivated land area to replace agricultural production concentration. It can be seen that the conclusions drawn in the baseline regression are still valid.

Table 5. Estimation of cultivated land area

\begin{tabular}{|c|c|c|c|c|}
\hline & $\begin{array}{l}\text { Operation } \\
\text { income }\end{array}$ & $\begin{array}{l}\text { Remuneration } \\
\text { income }\end{array}$ & $\begin{array}{l}\text { Property } \\
\text { income }\end{array}$ & Gini coefficient \\
\hline $\begin{array}{l}\text { Period*Agricultural cultivate } \\
\text { land area }\end{array}$ & $\begin{array}{c}\text { ed } 73.177^{* * *} \\
(15.867)\end{array}$ & $\begin{array}{l}48.031 * \\
(28.198)\end{array}$ & $\begin{array}{l}4.386^{*} \\
(1.954)\end{array}$ & $\begin{array}{l}-0.003 * \\
(0.001)\end{array}$ \\
\hline \multirow[t]{2}{*}{$\begin{array}{l}\text { Agricultural cultivated lan } \\
\text { area }\end{array}$} & $\begin{array}{l}\text { nd } 294.095 * * * \\
\quad(57.44)\end{array}$ & $\begin{array}{l}-220.018^{* * *} \\
(62.74)\end{array}$ & $\begin{array}{l}-6.779 \\
(9.219)\end{array}$ & $\begin{array}{l}0.010 \\
(0.005)\end{array}$ \\
\hline & $-10.722 *$ & $92.676^{* * *}$ & $1.835^{*}$ & 0.000 \\
\hline \multirow[t]{2}{*}{ Urbanization } & $(4.778)$ & $(8.183)$ & $(0.737)$ & $(0.000)$ \\
\hline & $-379.509 * *$ & $1523.255^{* * *}$ & 13.335 & 0.017 \\
\hline \multirow[t]{2}{*}{ Average educational level } & $(-122.401)$ & $(-230.573)$ & $(-19.029)$ & $(-0.011)$ \\
\hline & 1.514 & $70.937 * * *$ & $8.529 * * *$ & $-0.003 * * *$ \\
\hline \multirow[t]{2}{*}{ Primary industry } & $(6.854)$ & $(13.478)$ & $(1.033)$ & $(0.001)$ \\
\hline & $795.449 * * *$ & $838.109^{* *}$ & 8.878 & 0.005 \\
\hline Labor alternative technology & $(137.622)$ & $(282.796)$ & $(21.681)$ & $(0.022)$ \\
\hline \multirow[t]{2}{*}{ technology } & $\begin{array}{l}\text { ve } 122.604^{*} \\
(47.684)\end{array}$ & $\begin{array}{l}3.279 \\
(89.67)\end{array}$ & $\begin{array}{l}-25.271^{* * *} \\
(7.347)\end{array}$ & $\begin{array}{l}0.000 \\
(0.005)\end{array}$ \\
\hline & -9.318 & $38.585^{*}$ & 2.354 & 0.001 \\
\hline \multirow[t]{2}{*}{ Financial support } & $(9.530)$ & $(17.921)$ & $(1.323)$ & $(0.001)$ \\
\hline & -0.22 & 0.284 & -0.051 & 0.000 \\
\hline Market openness & $(0.489)$ & $(1.030)$ & $(0.077)$ & $(0.000)$ \\
\hline Regional characteristics & control & control & control & control \\
\hline Time characteristics & control & control & control & control \\
\hline $\mathrm{N}$ & 670 & 670 & 670 & 533 \\
\hline $\mathrm{R}^{\wedge} 2$ & 0.92 & 0.73 & 0.68 & 0.08 \\
\hline
\end{tabular}

\section{Further Analysis the Influence Mechanism}

As mentioned above, cooperative management has an impact on farmers' income by improving the production efficiency of traditional agriculture and optimizing the utilization of labor elements. Among them, the transformation from traditional small-scale agricultural management to cooperative management has certain institutional advantages, and its potential profit constitutes the internal driving force for farmers to adopt cooperative management, which is also the "direct effect" of cooperative operation on agricultural income. Compared with the understanding of "direct effect", the influence mechanism of "indirect effect" needs to be further confirmed. If the cooperative operation does affect the farmers' income through the optimal utilization of labor elements, then the promulgation of the "Law of Farmers' Professional Cooperatives" will have an impact on the employment choice of labor force in areas with high concentration of agricultural production. Therefore, this paper verifies that the promulgation of the "Law of Farmers' Professional Cooperatives" has an impact on the employment choice of farmers in areas with high

Next, in order to test the impact of the promulgation of the "Law on Farmers' Professional Cooperatives" to the employment choice of rural labor force, this paper construct the following test model: 


$$
\text { Labour }_{j t}=\beta+\beta \text { Agri_Pro_Con }{ }_{j t} \times \text { Post }_{t}+\beta_{2} \text { Agri_Pro_Con }{ }_{j t}+\alpha \text { Control }_{j t}+d_{\mathrm{t}}+\gamma_{j}+\xi_{j t}
$$

Among them, Labour represents the employment choice of rural labor force, and the rest symbols are consistent with formula (8). According to the regression results in the second column of table 7, the coefficient $(-0.003)$ means that when the concentration of agricultural production is increased by $1 \%$, the number of non-agricultural employment will decrease by $0.3 \%$. Correspondingly, the regression results in the third column of table 7 show that the concentration of agricultural production has a positive effect on the employment in agriculture, which passes the significance test at the statistical level of $1 \%$. The coefficient of 0.011 indicates that when the concentration of agricultural production is increased by $1 \%$, the number of rural employment will increase by $11 \%$. In the traditional agricultural economy, due to the technical rigidity of non-agricultural employment, part of the labor force is trapped in the agricultural economy, which makes the utilization rate of labor elements not efficient. Under the cooperative operation mode, the cooperative not only liberates the labor force through large-scale production, but also absorb labor force by creating new occupation demand, so that the utilization of labor force is optimized.

Table 7. Estimation of cooperative management on farmers' employment choice

\begin{tabular}{|c|c|c|c|c|c|}
\hline & $\begin{array}{l}\text { External } \\
\text { employment }\end{array}$ & $\begin{array}{l}\text { Internal } \\
\text { employment }\end{array}$ & & $\begin{array}{l}\text { External } \\
\text { employment }\end{array}$ & $\begin{array}{l}\text { Internal } \\
\text { employment }\end{array}$ \\
\hline $\begin{array}{l}\text { Period*Agri-production } \\
\text { concentration }\end{array}$ & $\begin{array}{l}-0.003 * * \\
(0.002)\end{array}$ & $\begin{array}{l}0.011 * * * \\
(0.003)\end{array}$ & $\begin{array}{l}\text { Period*Agri-production } \\
\text { concentration }\end{array}$ & $\begin{array}{l}-0.006 * * * \\
(0.002)\end{array}$ & $\begin{array}{l}0.009 * * \\
(0.004)\end{array}$ \\
\hline Agr-production concentration & $\begin{array}{l}-0.023 * * * \\
(0.005)\end{array}$ & $\begin{array}{l}-0.048 * * * \\
(0.010)\end{array}$ & $\begin{array}{l}\text { Agr-production } \\
\text { concentration }\end{array}$ & $\begin{array}{l}-0.030 * * * \\
(0.006)\end{array}$ & $\begin{array}{l}0.016 \\
(0.013)\end{array}$ \\
\hline Urbanization & $\begin{array}{l}0.005^{* * *} \\
(0.000)\end{array}$ & $\begin{array}{l}-0.001 \\
(0.001)\end{array}$ & Urbanization & $\begin{array}{l}0.004 * * * \\
(0.001)\end{array}$ & $\begin{array}{l}0.002 \\
(0.001)\end{array}$ \\
\hline Average educational level & $\begin{array}{l}0.056 * * * \\
(0.013)\end{array}$ & $\begin{array}{l}-0.079 * * * \\
(0.027)\end{array}$ & Average educational level & $\begin{array}{l}0.046^{* * *} \\
(0.013)\end{array}$ & $\begin{array}{l}-0.068 * * \\
(0.028)\end{array}$ \\
\hline Primary industry & $\begin{array}{l}0.002 * * \\
(0.001)\end{array}$ & $\begin{array}{l}0.000 \\
(0.002)\end{array}$ & Primary industry & $\begin{array}{l}0.002 * * \\
(0.001)\end{array}$ & $\begin{array}{l}-0.001 \\
(0.002)\end{array}$ \\
\hline Labor alternative technology & $\begin{array}{l}0.120 * * * \\
(0.015)\end{array}$ & $\begin{array}{l}0.100 * * * \\
(0.030)\end{array}$ & Labor alternative technology & $\begin{array}{l}0.095 * * * \\
(0.015)\end{array}$ & $\begin{array}{l}0.117 * * * \\
(0.032)\end{array}$ \\
\hline $\begin{array}{l}\text { Non labor alternative } \\
\text { technology }\end{array}$ & $\begin{array}{l}-0.009 \\
(0.005)\end{array}$ & $\begin{array}{l}-0.043^{* * *} \\
(0.011)\end{array}$ & $\begin{array}{l}\text { Non labor alternative } \\
\text { technology }\end{array}$ & $\begin{array}{l}-0.013^{* *} \\
(0.005)\end{array}$ & $\begin{array}{l}-0.053^{* * *} \\
(0.011)\end{array}$ \\
\hline Financial support & $\begin{array}{l}-0.005^{* * *} \\
(0.001)\end{array}$ & $\begin{array}{l}0.000 \\
(0.002)\end{array}$ & Financial support & $\begin{array}{l}-0.004 * * * \\
(0.001)\end{array}$ & $\begin{array}{l}0.000 \\
(0.002)\end{array}$ \\
\hline Market openness & $\begin{array}{l}0.000 * * * \\
(0.000)\end{array}$ & $\begin{array}{l}-0.000 * * * \\
(0.000)\end{array}$ & Market openness & $\begin{array}{l}0.000 * * * \\
(0.000)\end{array}$ & $\begin{array}{l}-0.000 * * * \\
(0.000)\end{array}$ \\
\hline Regional characteristics & control & control & Regional characteristics & control & control \\
\hline Time characteristics & control & control & Time characteristics & control & control \\
\hline $\mathrm{N}$ & 670 & 670 & $\mathrm{~N}$ & 670 & 670 \\
\hline $\mathrm{R}^{\wedge} 2$ & 0.73 & 0.29 & $\mathrm{R}^{\wedge} 2$ & 0.73 & 0.27 \\
\hline
\end{tabular}

\section{Conclusion and Policy Implications}

Under the background of the lagging development of agricultural economy, the widening income gap between urban and rural areas and the weak absorption of urban labor force, the impact of agricultural management organizations has been the focus of academic attention in recent years, but few studies have explored the impact of cooperative operation on farmers' income from the internal mechanism. In this paper, through the theoretical analysis of farmers' income and career choice in the traditional and cooperative management, and taking the promulgation of the "Law of Farmers' Professional Cooperatives" as the quasi natural experiment, applying the 1995-2018 National Household Survey Data, using the continuous DID model to verify the mechanism of cooperative operation on farmers' income.

The conclusion of this paper shows that the cooperative management plays a positive role in the increase of farmers' income and inhibits the distribution of farmers' income. As for its internal mechanism, this paper points 
out that the cooperative operation has certain institutional advantages over the traditional agricultural operation, its potential benefits can avoid the shortcomings of traditional agricultural operation, and then play a positive role in improving the income of farmers' operation. In addition, because the cooperative operation not only liberates but also absorbs rural labor force, it optimizes the utilization of labor elements in traditional agriculture, and then brings about the increase of labor remuneration and property income of farmers. Because, the two mechanisms have different paths to affect farmers' income, this paper defines the former as "direct effect" and the latter as "indirect effect". In addition to the above structural impact of farmers' income, this paper also points out that in the cooperative operation mode, due to the farmers' optimal career choice among the traditional agricultural management, cooperative operation, internal or external employment in agriculture, the labor force with various skill levels has more opportunity to obtain the optimum occupation compared with the traditional agricultural operation mode. In addition, further analysis of the mechanism of the optimal utilization of labor elements shows that cooperative operation has a stimulating effect on internal employment choice in agriculture, and has a restraining effect on external employment choice in agriculture. The conclusion of this paper has certain policy meaning for stimulating the internal power of agricultural development, optimizing the utilization of rural labor resources and reduce the contradiction between urban and rural development. Next, government departments should strengthen the policy design and implementation of cooperative management system, and effectively implement the transition from traditional agricultural management mode to cooperative operation mode.

\section{References}

Abebaw, D., \& Haile, M. G. (2013). The Impact of Cooperative on Agricultural Technology Adoption: Empirical Evidence from Ethiopia. Food Policy, 38, 82-91.

Develtere, P., Pollet, I., \& Wanyama, F. O. (2008). Cooperating Out of Poverty: The Renaissance of the African Cooperative Movement.

Fischer, F., \& Qaim, M. (2012). Linking Smallholders to Markets: Determinants and Impact of Farmer Collective Action in Kenya. World Development, 40, 1255-1268.

Hellin, J., Lundyb, M., \& Meijerc, M. (2009). Collective Action and Market Access in Meso-America. Food Policy, 34, 16-22.

Jianxiong, G., \& Zhijun, L. (2009). Agricultural Development Mechanism under the Condition of Selective Labor Transfer. Economic research, (5), 31-41.

Liyan, Y., Shaofeng, Z., \& Liangbiao, L. (2010). Analyze the Main Problems and Countermeasures of the Development of Farmers' Professional Cooperatives-Based on the Investigation and Analysis of Fujian Farmers' Professional Cooperatives. Exploration of Economic Problems, (9): 95-63.

Mercer, C. (2002). The Discourse of Maendeleo and the Politics of Women's Participation on Mount Kilimanjaro. Development and Change, 33, 101-127.

Minsheng, Z. (2009). Reflections on the Establishment and Development of Farmers' Professional Cooperatives in China. Economic Issues, (6), 96-98.

Qin, L., \& Qing, Z. (2013). Analysis on the Effect of Farmers' Professional Cooperatives in Guizhou Province to Increase Farmers' Income. Guizhou Social Science, (1), 105-108.

Qingliang, Z., Pin, L., \& Lian, H., \& Huanming, W. (2017). The impact of Farmers' Professional Cooperatives on the Increase of Farmers' Income--Taking Huaiyuan Pomegranate Professional Cooperatives as an Example. Economy and Management, (7), 39-42.

Shylendre, H. S. (2013). Microfinance and the Cooperatives: Can the Poor Gain from Their Coming Together? International Journal of Rural Management, 9, 151-181.

Valentinov, V., \& Iliopoulos, C. (2013). Economic Theories of Nonprofits and Agricultural Cooperative Compared: New Perspectives for Nonprofit Scholars. Nonprofit and Voluntary Sector Quarterly, 42, 109-126.

Vandeplas, A., Minten, B., Swinnen, J., \& Multinationals, V. S. (2013). Cooperative: The Income and Efficiency Effect of Supply Chain Governance in India. Journal of Agricultural Economics, 64, 217-244.

Verhofstadt, E., \& Meartens, M. (2015). Can Agricultural Cooperatives Reduce Poverty? Heterogeneous Impact of Cooperative Membership on Farmers' Welfare in Rwanda. Applied Economic Perspectives and Policy, $35,86-106$. 
Wen, X., Yajing, F., \& Qi, L. (2019). Research on the Impact of Farmers' Participation in Farmers' Professional Cooperatives on Their Income and Financial Assets. Financial Theory and Practice (Bimonthly), (3), 149-154.

Wenhuan, P., \& Zuhui, H. (2017). Do Farmers' Professional Cooperatives Increase Farmers' Income? . An Investigation Based on Endogenous Transformation Model and Cooperative Service Function. Journal of Northwest A \& F University (SOCIAL SCIENCE EDITION), (4), 57-66.

Xiaoping, W. (2012). Farmer Professional Cooperatives: the Booster of Agricultural Modernization. Newsletter About Work in Rural Areas, (12), 35.

Yafan, S. (2003). An Empirical Study on the Demand and Willingness of Farmers' Cooperation in China-An Empirical Investigation and Analysis of Farmers in Jiangsu. Jiangsu Social Sciences, (1), 204-208.

Yanhua, S., Li, Z., \& Ruiyao, Y. (2007). Research on the Income Increase Performance of Farmers' Professional Cooperatives -- Based on the Analysis of the Aurvey Data of Chicken Farmers in Jiangsu Province. Journal of Nanjing Agricultural University (Social Science Edition), (2), 22-27.

Yuxin, L. (2017). Research on the Impact of Farmland Transfer on Farmers' Income by Agricultural Machinery Cooperatives-Taking the Standardized Cooperatives of Agricultural Machinery Cooperatives in Heilongjiang Province as an Example.

\section{Copyrights}

Copyright for this article is retained by the author(s), with first publication rights granted to the journal.

This is an open-access article distributed under the terms and conditions of the Creative Commons Attribution license (http://creativecommons.org/licenses/by/4.0/). 